\title{
Children, Technology and Social Values: Enabling Children's Voices in a Pluralistic World
}

\section{Authors}

Theresa Anderson

Faculty of Arts and Social Sciences, University of Technology, Sydney

Sydney, NSW, Australia

Email: anderdorfer@gmail.com

Allison Druin

The College of Information Studies, University of Maryland

College Park, Maryland

Email: allisond@umiacs.umd.edu

Kenneth Fleischmann

The College of Information Studies, University of Maryland

College Park, Maryland

Email: kfleisch@umd.edu

Eric Meyers

The School of Library, Archival, and Information Science, University of British Columbia Vancouver, BC, Canada

Email: eric.meyers@gmail.com

Lisa Nathan

The School of Library, Archival, and Information Science, University of British Columbia Vancouver, BC, Canada

Email: lisapnathan@gmail.com

Kristene Unsworth

The Information School, University of Washington

Seattle, Washington

Email: kruns@u.washington.edu

The landscape of childhood in the 21st century increasingly involves technology. As information and communication technologies (ICTs) become ubiquitous in homes, schools, libraries, and play spaces, children are plugged-in and online with greater frequency and at a younger age. Concerns regarding new and emerging technologies like the immersive Internet, mobile phones, and social networking sites often lead to highly charged, emotive responses aimed at reducing the risks associated with such technologies. These reactions focus our attention on children in the role of victimized consumer, and privilege the perspective of a single stakeholder, the parent. This desire to protect young technology consumers runs contrary to the participatory techniques intended to give greater voice to users in the design and development of technology. A broader, more enlightened perspective on the role of technology in the lives of children recognizes the multiple roles, stakeholders, and value propositions which affect these interactions with ICTs. Rather than casting children in the limited role of consumer of technology, participatory and value-sensitive design techniques afford children the role of tester, evaluator, appropriator, remediator, co-designer, or co-investigator. Creating and sustaining a pluralistic society means providing sufficient opportunities for the voices of children in the decisions that affect their lives and their futures. This panel will ground this discussion in current empirical research studies where a child's voice is actively sought as part of the design and evaluation of technologies as an 
opportunity to speculate about the need to go further in ensuring that children are active participants in the decision making process. The panel will invite discussion about ways that the information science community could be taking a far more active role in terms of awareness raising, advocacy and mediation between all the various stakeholders to enable a stronger voice for children in society.

\section{Introduction}

The landscape of childhood in the 21st century increasingly involves technology. As information and communication technologies (ICTs) become ubiquitous in homes, schools, libraries, and play spaces, children are plugged-in and online with greater frequency and at a younger age (Harwood \& Asal, 2007). Parents, educators, and researchers have raised concerns about how children interact in online space, the safety and privacy of interactive technologies for children, and the difficulties of providing age-appropriate play and learning opportunities for connected youth (Bogost, 2008; British Library, 2008; Gee, 2008). These include technologies designed expressly for children, as well as adult technologies which children appropriate for academic tasks, entertainment, and communication. Concerns regarding new and emerging technologies like the immersive Internet, mobile phones, and social networking sites often lead to highly charged, emotive responses aimed at reducing the risks associated with such technologies (Bederoff, 2007; Flanagan, 2007). These reactions focus our attention on children in the role of victimized consumer, and privilege the perspective of a single stakeholder, the parent. Consequently, children and young people can become disempowered in decisions about how they use technologies, as well as how technologies are designed to meet their needs and activities. This desire to protect young technology consumers runs contrary to the increasingly participatory techniques intended to give greater voice to all users in the design and development of the very technologies they are using (Flanagan, Howe, \& Nissenbaum, 2005).

A broader, more enlightened perspective on the role of technology in the lives of children recognizes the multiple roles, stakeholders, and value propositions which affect interactions with ICTs. Rather than casting children in the limited role of consumer of technology, participatory and value-sensitive design techniques afford children the role of tester, evaluator, appropriator, remediator, co-designer, or co-investigator (Druin, 2002; Meyers, Fisher, \& Marcoux, 2007).

Creating and sustaining a pluralistic society means providing sufficient opportunities for the voices of children as well as adults in the decisions that affect their lives and their futures. This panel will ground discussion in current empirical research studies where a child's voice is actively sought as part of the design and evaluation of technologies as an opportunity to speculate about the need to go further in ensuring that children are active participants in the decision making process. The panel will invite discussion about ways that the information science community could be taking a far more active role in terms of awareness raising, advocacy and mediation among the various stakeholders to enable a stronger voice for children in society.

\section{Background}

This panel provides an opportunity for discussion and awareness-raising about the need to do more to bring children into conversations (politically, socially, technically) about their access to and use of technologies. Participatory design approaches and frameworks have been employed in projects around the world to enable children's voices to be more present in the design, development and implementation of technologies like the internet, mobile phones, and social networking sites. However, there is a need to move beyond the advances made using participatory approaches to technology design. We need to begin thinking through the consequences for our communities and societies with regards to the risk landscape that is taking shape for our children. This presentation will serve to start this discussion. Panelists will share 
projects involving children in the design of mobile phones in ways enabling children to have more voice in the design process whilst countering the concerns many adults have about children needing to be 'protected' from technology (such as mobile devices, social networking sites, etc).

Research by Christensen and Mikkelsen (2008), for example offers a way to view the risk landscape of our children as one where children have a chance to develop their ability to assess and handle risk, chance, and uncertainty in their everyday practice. They acknowledge that parents, teachers and other adults involved with children in their everyday lives play an active part in guiding children and on occasion "saving them from inexperience and misjudgment". But their research also demonstrates that children already possess individual and collective efforts for assessing risks in their everyday games and relationships with other children:

"Children's willingness to take risks, make mistakes and find solutions forms an important part of their collective learning." It seems to be "...performed as a balancing act between risk willingness and self-care" (p. 127).

While it is important to minimize risks, there is also a danger that the responses of adults to the new and emerging technologies essentially remove opportunities for children to develop the "risk taker's advantage” that research like that of Christensen and Mikkelsen (2008) would suggest children can only acquire through experience.

Christensen and Mikkelsen (2008) further elaborate that we need to explore the meaning of risk to children and "...how they develop their agency in taking and handling the risks they encounter ... In summary, adults might join in, support and engage with the risk management that children are already practicing” (p. 128).

This research finds that children need opportunities to develop their abilities to take risks and learn to manage them.

Giving children the risk-taker's advantage in relation to information and communication technologies begins with giving them a greater voice in the decisions surrounding their access to and use of such technologies. Two key questions for the panel and the audience are:

How are we to handle these risks and help children to handle these risks?

How can we extend existing participatory programs associated with design of technologies to designing the infrastructures, services and policies that will shape children's lives and use of technology?

\section{Structure and Format of the Panel}

The panel will integrate a series of case examples involving the application of participatory and value-sensitive approaches to the design, evaluation, and use of youth-centered technologies. By illustrating these approaches with empirical work, we ground our philosophical discussion in real-world research and design practice. The panel presenters will elaborate on how they bring the child's perspective into the investigative and design processes with philosophical discussions of the values that are and/or should be informing work with children's technologies. Each project will present questions designed to foster discussion with the audience and among panelists about the implications that work in the spirit and form of that presented may hold for software developers, interaction designers, youth service providers, and researchers. The panel presentations will close by inviting the audience to discuss the implications of current trends for various sectors of the community (e.g., policy makers, parents, teachers, AND designers) that will have an impact on the future of children. 


\title{
Presenters: Case Studies \& Philosophical Discussions about Children, Technology, and Values
}

\author{
“Tensions on the Digital Playground: Safety, Surveillance, and Values in Preteen Virtual \\ Worlds" \\ Eric M. Meyers and Lisa P. Nathan, University of British Columbia; Kristene Unsworth, \\ University of Washington
}

Cyber-stalking. Cyber-bullying. Cyber-tattling. These recently minted terms have become part of the conversation around children's online interactions. How do designers, parents, educators, and - most importantly — the children themselves understand and address these issues? How do emerging technology environments afford or constrain these types of behaviors? Meyers, Nathan, and Unsworth will introduce a critical, values-oriented investigation of a specific segment of the online universe: shared virtual playgrounds designed for preteens. This investigation focuses on the sites' technical features designed to support value concerns (e.g. privacy, security, obedience) and critically examines the potential influence of these features from different stakeholder perspectives. We provide a conceptual framework for analyzing these online environments, drawing upon methods from Value Sensitive Design (Friedman, Kahn, \& Borning, 2006) and inspired by work to envision the long-term influence of information systems (Nathan et al., 2008). This presentation will outline: 1) the field based investigation gathering designer, parent, and children's perceptions of preteen virtual worlds; 2) the research agenda for the critical study of children's virtual environments as value-laden artifacts; and 3) implications such work may hold for the design and evaluation of these spaces in a variety of domains.

\section{“The Mobile Childhood: the Interplay between Technology and Sociality” Theresa Anderson, University of Technology Sydney}

How are children and young people affecting, and affected by, the development and popularity of mobile information communications technologies? What are the social impacts on their lives? How are media policy and regulatory environments adapting to changes in the lives of children prompted by their adoption of mobile technologies and applications? What are the implications for policy makers, commercial operators, and child advocates? These are the key questions fueling a three-year project exploring the impacts of mobile phones on the lives of young people and the institutional responses to those impacts. Anderson discusses how social informatics and value sensitive design principles and practices can be applied to make children's voices - their wishes, desires and imaginative applications - more present in the design, development and application of mobile phone technologies intended for use by children and young people. She uses the example of a current project investigating how, why, and with what effects children and young people are using mobile telephony in Australia. The project involves young people and pre-teens from a variety of socio-political backgrounds as co-researchers in a three year review of the role of mobile communications in the development of social structures and friendship networks. Anderson speculates about ways to resolve the emerging tensions between the children's practices and the concerns voiced by adult decision makers about the need to protect children from dangers associated with mobile phone use.

\section{“Children as Activists, Policymakers, and Designers: Students, Frogs, Laws, and Technology" Ken Fleischmann, University of Maryland}

Do you have to be old enough to vote to change the world? Apparently not, as demonstrated by the role of middle- and high-school students in the creation of dissection choice laws. These students are able to simultaneously serve as activists, promoting the cause of animal advocacy; policymakers, in bringing about new laws that shape not only themselves but also millions of other students; and designers, in the impact that they are able to have on if and how frog 
dissection simulations are designed. Frog dissection simulations provide a compelling example of how values can be embedded in information technology; specifically, the animal advocacy values of students. This presentation will discuss findings of a multi-sited ethnographic study that involved interviews with 61 students, teachers, administrators, activists, and designers. The presentation will also reflect on recent developments that have occurred since this study, including the increasing role of No Child Left Behind on both physical and virtual science laboratory exercises. Finally, the presentation will conclude with a discussion of the ethical implications of doing research involving children and, more importantly, of not doing research involving children (i.e., not only do we have a moral obligation to take extra precautions when doing research with children, we also have a moral obligation not to allow such precautions from preventing us from involving children in design, since children have to interact with the built world just as much as adults, which is especially important given how easily children's development can be influenced by technology and the extent to which today's children will be engaged with technology throughout their lives).

\section{"Changing what Can be Changed with Children and Technology" Allison Druin, University of Maryland}

What do "People in Need" (peopleinneed.info/index.php/site/), the "President's Park" (www.nps.gov/whho/) and the "International Children's Digital Library"

(www.childrenslibrary.org) have in common? All are Internet sites that have given children a voice in the design and redesign of their software/site. Eight children, ages 7-11 years, are partnering with our faculty, staff, and students at the Human-Computer Interaction Lab at the University of Maryland. Together we are reshaping the People in Need site for children so that young people can help to change what is possible in Haiti. At the same time, National Park Service professionals are partnering with our team to change what is said about the "President's Park". At the same time, young people from around the world are working with our team to redefine the online searching and reading experience. Children's ideas of how to end poverty, offer government information online, and even read books from 60 countries, are changing what can be changed with technology. In this panel talk Druin will present the teams' design methods and work-to-date with children.

\section{Acknowledgements \\ References}

Benderoff, E. (2007, 8 March). Cheating a real problem in Club Penguin's virtual world. The Chicago Tribune. Retrieved 10 April, 2008 from http://www.chicagotribune.com/business/chi0703080167mar08,0,4256114.story

Bogost, I. (2008). The rhetoric of video games. In K. Salen (Ed.), The ecology of games: Connecting youth, games, and learning. The John D. and Catherine T. MacArthur Foundation Series on Digital Media and Learning (pp. 117-140). Cambridge, MA: The MIT Press.

British Library \& Joint Information Systems Committee (JISC) (2008, 11 January). The information behavior of the researcher of the future: A Ciber briefing paper. Retrieved 17 January 2008 from http://www.jisc.ac.uk/media/documents/programmes/reppres/gg_final_keynote_11012008.pdf

Christensen, P., \& Mikkelsen, M. R. (2008). Jumping off and being careful: children's strategies of risk management in everyday life. Sociology of Health \& Illness, 30(1), 112-130.

Druin, A. (2002) The role of children in the design of new technology. Behaviour and Information Technology, 21(1), 1-25.

Flanagan, C. (2007, July). Babes in the woods. Atlantic Monthly, 300(1), 116-133. Retrieved 27 July, 2007, from Academic Search Complete database. 
Flanagan, M., Howe, D. C., \& Nissenbaum, H. (2005). Values at play: Design tradeoffs in socially-oriented game design. Proceedings of the CHI 2005 conference on Human factors in computing systems. CHI 2005, April 2-7, 2005, Portland, Oregon. New York: ACM Press.

Friedman, B., Kahn, P. H., Jr., \& Borning, A. (2006). Value Sensitive Design and information systems. In P. Zhang \& D. Galetta (Eds.), Human-computer interaction and management information systems: Foundations (Vol. 1, pp. 348-372): M.E. Sharpe.

Gee, J. P. (2008). Learning and games. In K. Salen (Ed), The ecology of games: Connecting youth, games, and learning. The John D. and Catherine T. MacArthur Foundation Series on Digital Media and Learning (pp. 21-40). Cambridge, MA: The MIT Press.

Harwood, P. G., \& Asal, V. (2007). Educating the first digital generation. Westport, CT: Praeger.

Meyers, E. M., Fisher, K. E. \& Marcoux, E. L. (2007). Studying the everyday information behavior of tweens: Notes from the field. Library and Information Science Research, 29 (3), 310331.

Nathan, L.P., Friedman, B., Klasnja, P.V., Kane, S.K., \& Miller, J.K. (2008). Envisioning systemic effects of interactive technical systems. Proceedings of the Conference on Designing Interactive Systems (DIS ‘08), 1-10, Cape Town, South Africa.

\section{Appendix \\ Footnotes}

